\title{
Celebrating Female Desire in the Medieval Era: an Exegesis of the Erotic Verses from Jayadeva's Gītagovinda
}

\author{
Tirthendu Ganguly \\ Ph.D. Research Scholar, Department of English, Faculty of Arts, Banaras Hindu University. \\ ORCID: 0ooo-0oo2-0957-5295. Email: tirthaforyou7@gmail.com,
}

\begin{abstract}
Discussing women's sexual desire has long been perceived as a taboo in the East and the West as well. Undeniably, there is a stigma attached to it which, unfortunately, continues even today. However, surprisingly enough, the ancient and the medieval Indians had always been open to female sexuality before their philogynist culture was obliterated and replaced by the 'zenana culture' of the Mughals and the 'Victorian morality' of the British Raj. Even in the Medieval Era, which is often labelled as conservative and orthodox, people accepted female desire as a biological reality. Composed in twelve cantos, Jayadeva's magnum opus, Gitagovinda, celebrates sexuality and candidly depicts female orgasm with sheer poetic acumen. Jayadeva has not only eradicated the stigma attached to it, but he has also delineated it from the aesthetical perspectives of the Sanātana Dharma which makes it "a unique work in Indian literature and a source of religious inspiration in both medieval and contemporary Vaisnavism" (Miller, 1984). In this paper endeavours to analyze, assemble, and demonstrate how the poet has celebrated female psyche, female sexuality, and female orgasm in the $12^{\text {th }}$ Century CE. The paper deals with the primary aspects of the book which are related to female mind and sexuality. Library method of research has been carried out to substantiate the claims that this research paper makes. As the book is originally composed in Sanskrit, the research paper contains many Indic names and words which are written in accordance with the International Alphabet for Sanskrit Translitearation (IAST) method.
\end{abstract}

Keywords: Jayadeva; Gìtagovinda; female sexuality; female orgasm; female psyche.

\section{Introduction}

A woman's psyche plays a quintessential role in her attainment of orgasm (or any other form of sexual pleasure), and perhaps, it is upon this very notion that Jayadeva has modelled his Gitagovinda. Since a woman's psyche is undeipherably complex, the conditions which stimulate a woman's sexual feelings and bring forth her satisfaction are so profoundly puzzling that they can even overwhelm the great psychologists (Jones, 1953, p. 421). This is why, the course of the entire poem is richly manifold, complex, and varied. According to Goethe, female mood and sexuality which the poem ebulliently analyzes are confounding because of "the extremely varied motives by which an extremely simple subject is made endless” (Schmitz, 1909, p. 395). The entire poem deals with the dalliance of love between the two perennial lovers in Indian tradition, Rādhā and Kṛṣna. Whereas the character of Kṛṣna has received abundant glorification and has been portrayed in the Sanskrit litearure many a times, the celebration of Rādhā has been limited. But, Gìtagovinda

(C) AesthetixMS 2020. This Open Access article is published under a Creative Commons Attribution Non-Commercial 4.0 International License (http://creativecommons.org/licenses/by-nc/4.0/), which permits non-commercial re-use, distribution, and reproduction in any medium, provided the original work is properly cited. For citation use the DOI. For commercial re-use, please contact editor@rupkatha.com. 
primarily deals with the diverse moodswings of Rādhā, and that is how it has earned this complex development of plot.

\section{Complexity of the Female Mind and Sexuality}

In Gìtagovinda, Rādhā is "neither a wife, nor a worshipping rustic playmate. She is an intense, solitary, proud female who complements and reflects the mood of Kṛṣna's passion” (Miller, 1984). The desires and the moods of Rādhā are as complex as her psyche. In Jayadeva's poem, Rādhā has been idealized not as a goddess, but rather as a woman. She has been employed as a universal emblem for womanhood. Therefore, she reflects the perpetually complex moods of a woman. For example:

"When one of Rādhā's friend informs her that Kṛṣna is pining for the company of Rādhā, she feels immense delight and an utmost urge to submit herself to Kṛ̣na’s love. But the very act that Kṛṣna has sent her friend as an emissary of his plight rather than turning up himself, makes her sulky and hurt. Previously, Kṛṣna had shown affections for other women. And now, he has insolently dared to ask her to visit him rather than coming to her by himself. So, she sulks again. This complex thought of the lady has propelled Jayadeva to title the sixth canto as 'Dhrssta Vaikunțha', meaning 'Insolent Kṛ̣̦na'.” (Mandal \& Das, 2009, p. 132)

She is such a beloved lady who sulks with her lover when she finds him enjoying the company of the Gopīs, the cowherdesses who were friends to Rādhā and Kṛ̣na both. She often doubts her own friends, yet she tells them all her secret desires and sexual longings for Kṛṣna. She also chides her lover away at the very moment when her passion is deeply aroused to consummate with him. Although she rebukes Kṛ̣na, she cannot forget him and starts lamenting for losing her lover thus: "Though he is cruel to me, my heart cannot help being attached to him./The love that lotus-eyed women feel is unruly and perverse." (Siegel, 2009, p. 116). Not just that, Jayadeva delves deeper into the inner recesses of female mind. It is an open secret that every woman wishes to be recognized as superior to her fellow mates, and Rādhā is no different. She considers herself as the 'gopiśreșthā' (the greatest of the cowherdesses). That is why, when she finds her lover infatuated by the beauty of other women, she feels jealous. Just like an ordinary woman expects her lover to shower praising words on her beauty, Rādhā also craves the same from Kṛ̣nạ. She chides him at first, but Kṛ̣̣na eventually wins her heart back by obsequious persuasion.

\section{Impact of the Natural Environment on Female Sexuality}

Jayadeva narrates from the very beginning that a woman's sexual desire is deeply related to the atmosphere, environment, and the natural scenario. Not just that, Jayadeva also delineates the very environment in an erotic mode. The panorama of the whole atmosphere that Jayadeva creates through his poetic calibre is amply enticing. For example, the "darkness of the night in the forest is described in voluptuous sounds and imagery that echo through the entire poem. It is in this secret, sexually stimulating environment that Kṛṣna and Rādhā enact the initial triumph of their divine love" (Miller, 1984). The poet has described the springtime as the most ideal season when a woman feels the need for sexual gratification. The opening of the poem "concentrates on Kṛṣna's love with the cowherdess Rādhā in a rite of spring. Intense earthly passion is the example Jayadeva uses to express the complexities of divine and human love" (Miller, 1984). Time and again, nature has become instrumental in injecting passion in the female mind as the poem states: 
"It was springtime: her limbs delicate as primrose, Rādhā roamed the forest, searching high and low for Kṛṣna;

More and more distraught was she in love's feverish delirium, as her friend sang to her this sentimental song: When woeful women wail in want, lovelorn for lovers long away, As bakula bud bouquets burgeon into bloom with bumblebees in broad array, In springtime, the sensual season so languorously long for forlorn lovers, Kṛșna strays and plays, my friend, dancing with young girls." (Siegel, 2009, p. 18)

Not just the springtime, the serene moonbeams also germinate sexual urges in women. Rādhā confesses to her friend about how she burns in desire during the moonlit spring nights. The cool breeze, the spring season, and the moonshine together have been projected as a kind of natural aphrodisiac which stimulates a woman. Rādhā hums to herself in isolation that such a natural environment would lead any woman to lose control over her lust and indulge in such promiscuity which her honour does not permit otherwise. As Rādhā says:

"The moon that night was splendorous, a shining sandal spot on the brow of a dark supernal beauty;

Its glorious beams so radiantly illuminated the pathways within the woods of Vrinda That it was inopportune for loose ladies to steal out to meet their lovers;

It seemed as if the dark brand on the moon's face had been placed there as a punishment for having hindered lovers.

As that marked moon was rising, and Kṛ̣na still had not arrived, A bereft Rādhā cried out these doleful lamentations..." (Siegel, 2009, p. 100)

However, many Vaișnava critics have often interpreted it as the craving of the 'ätmā' to mingle with the 'paramātmā'. Thus, the very act of sexual arousal in a woman has been tacitly implied as a spiritual journey in which the whole universe takes part. In Jayadeva's Gìtagovinda, "Rādhā and Kṛṣna are vehicles (vībhava) for the universalization of erotic emotion” (Miller, 1984).

\section{Expressions of Female Desire}

The very opening canto of the Gitagovinda depicts how the Gopīs spontaneously manifest their desire to Krṣna without any sense of shame or guilt. The point that must be noted here is that they all try to seduce Kṛṣna together in front of each other without any fear or guilt despite being aware 
about Kṛ̣nạa's clandestine love affair with Rādhā. It needs no saying that even today in our society, such an act would be perceived as lechery. But, amusingly, Jayadeva has not condemned this act, but rather he has celebrated it as a liberation from the patriarchal norms of morality and chastity. By infusing spiritual significance with female sexuality, the poem's "place in the broader development of Indian religious eroticism is central" (Siegel, 1990). With richly embedded sexual words, the poem narrates how one cowherdess tries to show her lascivious breasts to Kṛṣna by bending down whereas the other shakes her callipygian bottom in a seductive manner during her dance while Kṛșna plays the flute. The sole sexual desire of women has been given a prominent utterance with conspicuous respect and poetic sensibilities thus:

"Heartily hugged by a cowherd's wife with bountiful beautiful breasts

Singing sexy vespers, her amorous behests;

Kṛṣna rollicks in a frolicsome flock of comely coy coquettes.

Another girl fixes his lotus face in her pensive gaze,

Winking and blinking are his eyes in their seductive ways;

Kṛṣna rollicks in a frolicsome flock of comely coy coquettes.

Another bonny-bottomed beauty beckons to whisper in his ear, And kisses him on his bristling cheek as soon as he comes near;

Krṣnna rollicks in a frolicsome flock of comely coy coquettes.

Another on the Yamuna's banks, eager for artful amorous play, Grabs his robe, and into a grove she tries to drag him away;

Kṛ̣na rollicks in a frolicsome flock of comely coy coquettes." (Siegel, 2009, pp. 24-26)

According to Mukhopadhyay (1928), Kṛṣna not only entertains their libertine approaches, but also requites their lust in every way possible. In order to do so, Kṛșna also has to put efforts as all the cowherdesses desire Kṛ̣na in their own different ways which once again exemplify the varied moods and means of sexual arousals that women feel (pp. 28-31). This variance of desire in women is what Jayadeva has exquisitely painted in his verses and he has susceptibly implicated the act as the varied ways in which the devotees worship the divinity. Thus, celebration of female orgasm has been linked and compared to 'bhakti', which is why, "the critical acclaim of the poem has been very high, but its frank eroticism has led many Indian commentators to interpret the love between Rādhā and Kṛ̣na as an allegory of the human soul's love for God” (Miller, 1984).

\section{Depiction of Female Orgasm}

The events that instigate Rādhā's sexual delights are highly eccentric and befuddling. They can be divided into three categories. The first one is when she recalls her past sexual encounters with Kṛ̣na. The reminiscence of old erotic raptures churns up an intense desire in her as she utters:

"The first time he made love to me, I was very shy;

I tried to speak and show him smiles;

As he loosened my skirt to uncover my thigh,

he cajoled me with his flattering wiles;

Please, dear friend, urge Kṛṣna to make love to me, 
to have a change of heart,

For I'm overwhelmed with a passion

that tears my heart apart.

I kissed him and held him in my arms, reclining on a bed of flowers;

Flowers fell from my disheveled hair, and like a cuckoo I faintly trilled

As he etched my breasts with his sharp nails, flaunting the arts of Love in which he is so skilled;

Please, dear friend, urge Kṛṣna to make love to me, to have a change of heart,

For I'm overwhelmed with a passion

that tears my heart apart." (Siegel, 2009, pp. 40-41)

Uncannily and bewilderingly, the second instance of her sexual feelings arise with the pain of being separated from her lover while she suspects and laments that her lover might be indulging into an amorous activity with her friends. Whereas thinking about the deceit tears her heart apart, the very thought of Kṛṣna's pleased face also brings delight to her mind. In an utterly surprising way, she starts blaming her friends and abuses them as nymphomaniac coquettes who cannot restrain their lust (Mandal \& Das, 2009, p. 168). Not only that, she also remarks that the desire to make love that women feel are so unwavering, undaunted, and irrefragable that it can drive them against their own interest (Mukhopadhyay, 1928, p. 109). The third category of Rādhā's arousal of sexual desire is after the climax of the poem which appears when Kṛșna eventually surrenders to her, bowing down before her feet. The bold and melodious explication of the female rapture has been recorded in this segment of the poem. Rādhā attains her orgasm when she becomes submissive to her lover Kṛ̣na while they consummate in the act of love. Rādhā's orgasm has been boldly delineated thus:

"When they started making love, as much a deadly battle as a sexy game, the girl, in an attempt to conquer her lover, did something rash-she got on top of him!

And then, because of all the energy that demanded, her pelvis stopped churning, her arms fell limp and loose, her bosom heaved, and her eyes closed." (Siegel, 2009, p. 180)

The poem also expounds the post-orgasm mood of Rādhā. The next morning, when Rādhā wakes up, she finds Kṛṣna glaring at her bare breasts which once again incites amorous feelings in her mind. She requests Kṛṣna to fondle her, to deck her with the ornaments, to poultice the sandalpaste on her body, to comb her hair, and finally to draw a tilaka tika between her eyebrows. All these scenes have been pictographically sketched by Jayadeva with his marvellous words.

\section{Eradication of the Stigma Attached to Female Orgasm}

Eradication of the stigma regarding female sexuality emerges with the appreciation and exploration of the natural biological fact which Jayadeva does exceptionally well. By amalgamating theology with female sexuality, Jayadeva has created a new euphoria for the 
connoisseurs of rasa and the litterateurs of bhakti. The poem has not only made an appeal to the common folks, but also to the scholars, receiving utmost veneration from both of them. That is why, it is justified to state that "the lyrical, religious eroticism of the Gitagovinda earned sainthood for Jayadeva and a wider audience for his poem" (Miller, 1984). The songs of Gìtagovinda are highly popular and influential in Bengali culture. The fifteenth century saint, Srī Caitanya, who was one of India's most celebrated socio-religious reformers and the founder of the Gaudiiya Vaiṣnava cult, adored the poem vehemently. He used to bless and embrace anyone who used to sing the lyrics of Gitagovinda to him (Dimock \& Stewart, 2000). The songs of Gitagovinda are sung everyday during the nightly worships at the Jagannātha Temple of Puri. Due to this theosophical aspect, the songs are sung throughout Orissa and Bihar with extreme reverence. Not just that, these songs are an "essential aspect of Odissi dance, which has developed through the art of religious dancers called Maharis who still dance Gìtagovinda songs before Jagannātha" (Miller, 1984). The songs are not merely limited to the Northern and Eastern regions of India, but expand to other parts as well. These songs have been instrumental sources for many of the South Indian dance forms. Because of the lyrical structure, songs are often termed as 'aștapadì and they are "sung daily in many of the temples in Kerala, as the pious Hindus consider it a devotional song of highest order" (Menon, 1964). In Nepal, these songs are sung during the Sarasvatī Pujā and the worship of Kāma and Rati (Hein, 1972, pp.267-71).

\section{Conclusion}

Jayadeva's Gitagovinda presents to us the aspects of female sexuality which not just appeal to the readers of theosophical literature, but also to the ordinary people. The candid way in which Jayadeva has elucidated the compendia of the female mind and sexuality in the $12^{\text {th }}$ Century CE, is very rare even among the modern poets and authors of present time. As Siegel (2009) observes, "when it comes to arousing the essential flavour of the erotic sentiment, nothing can compare to Jayadeva's clever poetry" (p. 191). How this trailblazing poetry of Jayadeva has shaped the foundations of the women's role in the later Gauḍiya Vaișnava literature is something which can be researched further. As Sen (1917) rightly observes that the Vaișnava literature of the Medieval Bengal (especially Kṛ̣ṇadāsa Kavirāja's Caitanya Caritāmṛta, Vṛndāvana Dasa Ṭhākura's Caitanya Bhāgavata, and Karṇapūra's Caitanyacandrodaya Nātakam et cetera) are heavily influenced by Jayadeva's erotic spirituality.

\section{References}

Seigel, L. (2009). Gìtagovinda: Love Songs of Rādhā and Kṛṣna by Jayadeva. NY: New York University Press.

Miller, B. S. (1984). Gitagovinda of Jayadeva: Love Song of the Dark Lord. New Delhi, India: Motilal Banarsidass Publishing House.

Mandal, P., \& Das, N. (2009). Śrí Śrī Gītagovinda of Jayadeva. Kolkata, India: Akshay Library.

Mukhopadhyay, U. (1928). Śrī Śrī Gītagovinda of Jayadeva. Kolkata, India: Vasumati Sahitya Mandir.

Jones, E. (1953). Sigmund Freud: Life and Work. London, England: Hogarth Press. (Vol. 2, Pt. 3, Ch. 16, p. 421)

Schmitz, L. D. (1909). Correspondence between Goethe and Schiller from 1794 to 1805 (Vol.2, p.395). London, England: G. Bell. 
7 Celebrating Female Desire in the Medieval Era: an Exegesis of the Erotic Verses from

Jayadeva's Gītagovinda

Siegel, L. (1990). Sacred and Profane Dimensions of Love in Indian Traditions as Exemplified in the Gītagovinda of Jayadeva. Oxford, England: Oxford University Press.

Dimock, Edward C., \& Stewart, Tony K. (200o). Caitanya Caritāmṛta of Kṛṣnadāsa Kavirāja: A Translation and Commentary. Cambridge, MA: Harvard University Press.

Menon, K. P. S. (1964). Ashtapadi Attaprakaram. Trivandrum, India: Kerala Univrsity Malayalam Series.

Hein, N. (1972). The Miracle Plays of Mathura. New Haven, CT. Yale University Press.

Sen, D. C. (1917). The Vaișnava Literature of Medieval Bengal. Kolkata, India: Calcutta University Press.

Tirthendu Ganguly is a Ph.D Research Scholar, Department of English, Faculty of Arts, Banaras Hindu University. In 2016, he received Vidyasagar Memorial Award for academic excellence. He was also sponsored by the Oxford Centre for Hindu Studies (OCHS, Oxford University) to explore the Vedas and the Upanishads. He is the author of the poetry book, Firefly of Love (ISBN: 9781794652149). His poetry and fictions have been published in various internationally reputed anthologies and journals. 